\title{
Naise kujutamine eesti nüüdisanekdootides: kriitiline ülevaade
}

\begin{abstract}
Indrek Ojam
Teesid: Artiklis tuleb vaatluse alla naise representatsioon eesti anekdootides, mis pärinevad aastatest 1960-2010. Anekdoodikorpusse kuulus 1869 nalja, milles naisele oli viidatud võimalikult neutraalsete sõnadega: ema, naine, abikaasa ja neiu. Uuringu tulemustest selgub, et naist ümbritsev ruum anekdootides on harilikult kodukeskkond; tema levinumateks suhtluspartneriteks on abikaasa, lapsed ja teised lähisugulased. Naljadest pooltes oli naine üksnes episoodiline tegelane; $32 \%$ juhtudest tehti anekdoodis nalja selgelt naise üle ja üksnes 18\% juhtudest oli naistegelane ise aktiivne osapool, kes nalja tegi. Uuringu tulemustest nähtuv pilt on üldjoontes vanamoeline ja seksistlik: naist on eesti anekdootides kujutatud eelkõige tänaseks aegunud vastandite kaudu. See on seletatav eelkõige anekdoodižanri enese staatilisusega: käibivate stereotüüpsete kuvandite suhtes kriitilisemat lähenemist tasub otsida pigem uuematest internetihuumori žanritest.
\end{abstract}

Märksõnad: eesti anekdoodid, feministlik kriitika, internetihuumor, sooline identiteet

\section{Sissejuhatus}

Käesoleva artikli ülesandeks on anda ülevaade naiste kujutamisest moodsates eesti anekdootides. Analüüs põhineb uuringul internetianekdootidest, mis pärinevad aastatest 1960-2010. Esmane eesmärk on võimalikult neutraalselt tähistatud tegelaste (naine, abikaasa, ema ja neiu) rolle uurides kaardistada naisi ümbritsev ruum, suhtluspartnerid, seksuaalse materjali osakaal ja naise aktiivsuse/passiivsuse määr naljas. Artikli teine siht on hinnata uuritavat materjali kriitiliselt ning vaagida selle suhteid sotsiaalse tegelikkusega. Enne konkreetsete uurimistulemuste tutvustamist kirjeldan teema mõistmiseks vajalikku konteksti: tutvustan soo-teemalise huumori uurimise probleemistikku ja viitan ülevaatlikult eesti lähiajaloo olulisematele sotsiaalsetele teguritele. Järgneb uuritava anekdoodikorpuse ja metodoloogia ülevaade, milles selgita- 
takse materjali kategoriseerimise põhimõtteid. Uurimistulemuste detailsem kajastamine lõpetatakse kriitilise poleemika ja teema võimalike tulevikuperspektiivide üle arutamisega.

\section{Sugu ja huumor}

Sugudevahelised suhted on ammusest ajast olnud naljade teemaks ja uurijad on seda kategooriat rõhutanud kui populaarsuselt kolmandat etniliste naljade ja poliitilise huumori kõrval. Leon Rappoport (2005: 102) väidab, et selle huumoriliigi kohta kehtib kolm üldtunnustatud arusaama: 1) seda leidub peaaegu kõikides maailma ühiskondades; 2) neid nalju räägivad mehed, kes on ka üldiselt sagedasemad naljade rääkijad, mille tõttu on loogiline, et naljades kasutatakse naissoost stereotüüpe; 3) naised naeravad meeste naljade üle ka siis, kui need on tehtud selgelt naiste kulul, mis aitab kaasa naljades sisalduvate stereotüüpide levimisele. Seksistlik huumor, nagu etnilinegi, põhineb ühe grupi kõrvutamisel teisega ning sellest tekkinud vastandusel "meie" ja "nemad". Kuna selliste naljade rääkijad on olnud peamiselt mehed, on aimatav, et "teise" roll (ka hierarhiliselt madalamal paiknev) jääb sellisel juhul naiste kanda. Selline meestekeskne vaatepunkt on leidnud ka kriitikat, eriti feministlikest paradigmadest lähtuvate uurijate poolt (Bing 2007; Shifman 2010).

Igapäevasuhtluses ette tuleval huumoril (nagu igasuguse lingvistilise suhtluse puhul üldiselt) on lisaks lõbu pakkuvale funktsioonile oma loomulik roll ka isiklikus ja kollektiivses identiteediloomes. See puudutab ka sooga seotud hoiakuid. Praeguseks on üldiselt aktsepteeritud vaatepunkt, et inimese sotsiaalne sugu on midagi aktiivse tegevuse poolt kujundatavat ehk sotsiaalselt konstrueeritav (Crawford 2003). Selline protsessuaalne arusaam on välja vahetanud vana essentsialistliku käsitluse, mille järgi sugu on selgelt fikseeritud omadus. Mary Crawfordi järgi toimub oma soo sotsiaalne ülesehitamine meeste ja naiste hulgas üldjoontes sarnaselt, kuid käibelolevate mehelikkuse ja naiselikkuse ideaalide tõttu erinevad rõhuasetused siiski selgelt (Crawford 2003: 1421-1424). Siinse uurimuse suhtes muutub soolise iseduse loomise protsess oluliseks, kui kujutleda uuritud materjali esitamissituatsiooni. Nõnda võime küsida kriitiliselt: 1) kas materjalis kohatava naisekuvandi on loonud naised ise või mehed; 2) mida ütleb see kuvand omakorda seda taastootva grupi identiteedi kohta?

Käesolevas uurimuses tihti ette tulev sõna "stereotüüp” märgib teatud hulka kultuuriteadvusse kinnistunud arusaamu naiste käitumise ja mõtlemise kohta. Stereotüüp on ähmane ja raskesti piiritletav mõiste. On raske öelda, kus lõpeb teatud arusaam või kuvand ja kust algab stereotüüp. Nii näiteks hoiatas 
briti üks juhtivaid huumoriuurijaid Christie Davies selle sõna kasutamise eest uurimustöös oma ettekandes 2011. aasta augustis Tartus huumoriuurimise suvekoolis. ${ }^{1}$ Stereotüübi mõiste kasuks räägib aga selle funktsionaalsus, mis on intuitiivselt hästi tajutav. Tõepoolest, kuna naljad põhinevad vastandustel, võime küsida, kas nad saaksidki üldse eksisteerida ilma stereotüüpideta. Kui üritada visandada mingisugust üldlevinud pilti, siis meedias ja reklaamides on kuni viimaste aastateni olnud kasutusel vana, binaarsetel opositsioonidel põhinev kuvand, mis esitab naist irratsionaalse, ebakindla, passiivse ja sõltuvana. See käibeopositsioon on muuhulgas ka hierarhiline, paigutades naise selgelt mehest allapoole. Siinne uurimus püüab läbi saada selliseid arusaamu rõhutamata, peitmata samas pead liiva alla tõsiasja ees, et selline kujutamine pole meediast ega huumori erinevatest avaldumisvormidest kuhugi kadunud.

\section{Naljade tõsidus ja solvavus}

Et siinse artikli positsioon on vaadeldava materjali suhtes kriitiline, tasub pöörata tähelepanu ka huumoriga seotud varjukülgedele. Teatud negatiivne ambivalentsus on eriti iseloomulik soolise ja etnilise temaatikaga naljade puhul. Osa huumori, eriti puändiga naljade puhul on teatud solvavus esiteks paratamatu struktuurne probleem - enamasti tehakse nalja ikka kellegi üle. Hea maitse ja nalja õnnestumise küsimus sõltub peale konkreetse teksti ka kontekstist, milles seda esitatakse. Seetõttu võib huumorit mõnes olukorras vaadelda kui sotsiaalse üleoleku demonstreerimist ja viisakuspiiride kompamist (Kuipers 2008: 382-385). Solvavuse ja vaenu piir võib olla väga kõikuv. See võib ulatuda leebest tögamisest otsese vaenu õhutamiseni. Nii pakub Michael Billig (2001) äärmusliku näite olukorrast, kus rassistlik kogukond kasutab kodulehekülgedel internetihuumorit üksnes leevendava modaalsusena oma varjamatult agressiivsete ja julmade vaadete levitamiseks.

Uurijad pole ühel meelel etniliste ja seksistlike (käesoleva uurimuse materjali üks põhilisi suundumusi) naljade rääkijate motiivide, s.t naljade ja naljavälise maailma suhete kohta üldiselt. See illustreerib raskusi, mis tekivad, kui hakata teatud hulga tekstide vaatlemise järel tegema üldistusi ja järeldusi. Nii on näiteks Christie Davies (1998; 2011) ja Elliot Oring (2003) arvamusel, et naljade mitmemõttelisus ja ähmasus on piisavad põhjused, et välistada nalja sisust tulenevad otsesed järeldused rääkija kavatsuste kohta. Pigem sotsiaalse fenomenina, mis toimib esitamise hetkel ja oma kontekstis, käsitleb huumorit ka Giselinde Kuipers (2006; 2008). Teised aga, näiteks Limor Shifman ja Dafna Lemish (Shifman \& Lemish 2010; 2011), näevad nalju selgelt sotsiaalset tegelikkust peegeldavate fenomenidena. Nende vaatepunktist ei ole nali 
kunagi "lihtsalt nali", kuivõrd selles peituvad alati implitsiitsena teatud (tihti iganenud) arusaamad mehelikkusest ja naiselikkusest. Lemish ja Shifman on võrdlemisi optimistlikud ka huumori kriitilise potentsiaali suhtes: huumori kaudu saavad ja peakski end kuuldavaks tegema marginaalsed grupid. Naiste kohta levivate naljade puhul on oluline, kui palju alamrühmi võib see hulk sisaldada: naljad lesbidest, ämmadest, prostituutidest, blondiinidest, USAs levivad Jewish American princessi (lühidalt JAP) naljad jpt. Nende sotsiaalsete gruppide aadressil käibivad anekdoodid on äärmiselt erinevad, mis seab uurija taas probleemi ette, keda need naljarühmad esindavad ja missugused järeldused on nende analüüsimisel võimalikud.

\section{Kohalikust ajaloolisest ja sotsiaalsest taustast}

Etniline või sooline huumor tekib alati teatud sotsiaalsete vastuolude mõjul. Sellepärast tasub tähelepanu pöörata ka naljade ajaloolisele kontekstile. Eesti materjali puhul ei saa eitada meie sotsialismijärgset olukorda, 1990. aastatel eriti intensiivseid ja praegugi jätkuvaid suuri muutusi ühiskonnas. Soohuumori vaatenurgast on oluline peremudeli muutumine traditsioonilisest laiendatud perekonnast tuumperekonna poole, kusjuures see trend jätkub ka praegu. Samuti väärib tähelepanu avalikkuse suhtumine väidetavalt mehelikesse ja naiselikesse isikuomadustesse ja ametitesse. Need erinesid ENSV ametlikus ideoloogias tugevalt tänapäevastest hinnangutest. Stanoy Stanoev visandab oma blondiininaljade tagamaid uurivas artiklis "Dumb blondes and democracy" (2010) vastava tausta Bulgaaria ajaloolise olukorra kohta. Mõned kirjeldatud tendentsidest on ilmselt täiesti otse üle kantavad Eestile ja teistele endistele idabloki riikidele. Üldiseimat neist tuntakse iseloomuliku topeltkoodina, mis rakendus erinevalt avaliku arvamuse ja inimeste isiklike tõekspidamiste kaudu. Näiteks nõukogude avaliku ideoloogia tekitatud olukord, mis üritades soorolle võrdsustada pigem kindlustas nende senist toimimist isiklikus elus (Stanoev 2010: 51).

Rääkides meeste stereotüüpsest suhtumisest naistesse, tasub arvestada ka tegureid, mis mõjutavad meeste endi enesemääratlust. Nõukogude kontekstis on täheldatav maskuliinse identiteedi nõrgenemine, sest meeste võimu ja otsustusjõudu tööl ja isiklikus elus oli kärbitud lausa riiklikult, rõhutades samal ajal naiste loomulikku õigust töötada kõikvõimalikes seni mehelikuks peetud ametites. Riikide taasiseseisvumise käigus toimus teatud nihe tagasi traditsioonilisemate soorollide poole, millest võib aimata meeste soovi taastada varasemat identiteeti. Tulemuseks oli aga konfliktne olukord naiste suhtes, kellel uue demokraatliku korra kohaselt oli täielik õigus tööturul ja avalikus 
elus meestega võrdselt konkureerida. Selles vastasseisus, mille mastaabid on Ida-Euroopa riikides olnud kindlasti erinevad, kannatasid eelkõige naised. Nagu näeme avalikest aruteludest meeste ja naiste palgalõhe üle, ei ole need vastuolud siiamaani lahenenud. Uuematest probleemidest väärib mainimist madal sündivus ja vähene abiellumine, samuti suurenev lahutuste arv. Naiste ja meeste suhetesse kaudsemalt puutuvatest teguritest tulevad arvesse etnilised konfliktid, alkoholi- ja teised rahvatervise probleemid, samuti suur väljaränne rikkamatesse riikidesse.

Kuigi siin loetletud protsesside omavahelised seosed ja mõjude määr on juba sotsioloogide uurimisteema, on mõistlik järeldada, et teatud jälje on need jätnud ka folkloori.

\section{Metodoloogia}

Puändiga nali ehk anekdoot, mille analüüs moodustab ka selle uurimuse keskme, on üks tüüpilisemaid ja folkloristi jaoks mugavamaid huumoriuurimise objekte. Selle esimeseks eeliseks on lihtsalt äratuntav ja võrdlemisi vähe muutuv struktuur. Uurijat aitab kindlasti ka naljade hea kättesaadavus ja jälgitavus internetiandmebaasides. Ilmselt ei vaja enam põhjendamist ka interneti enda kui normaalse suhtlemiskeskkonna usaldamine folkloori uurimiseks (lühike ülevaade internetihuumori uurimise spetsiifika kohta: Laineste 2003).

Käesolev uurimus taotleb suurimat võimalikku neutraalsust (mis on paratamatult tinglik, kuna tegu on anekdootidega), seega on naljade otsimiseks valitud märksõnad, mis olid võimalikult hinnangute- ja eelhoiakutevabad: naine, abikaasa, ema ja neiu. Selle tõttu jäid kaasamata otsingusõnad perenaine, blondiin, prostituut ja ämm. Eelmainitud märksõnad, nagu ilmselt ka naljad nende naisterühmade kohta, kannavad juba selgelt ettearvatavaid stereotüüpseid konnotatsioone (rumalus blondiinide ja seksiga seotud skriptid prostituutide puhul). Oluline on aga siinjuures fakt, et nimetatud rühmadega seotud nalju esines valimis sellegipoolest võrdlemisi palju, sest neutraalse märksõna esinemine naljas ei välistanud sealsamas teisi, vähem neutraalseid. Valimis esindatud naljade hulgas puudub eristus naljade vahel naistest või meestest, samuti pole määratletud, et naine peab naljas "füüsiliselt kohal viibima". Sellistel juhtudel on naisterahvas paljudes naljades pelk jututeema, kellele viitamiseks kasutatakse üht neljast märksõnast. Eelnevalt loetletud (naine, abikaasa, ema, neiu) nelja märksõna esinemine oligi esimeseks oluliseks tingimuseks, et nali valimisse pääseks. Teine oli arusaadavuse nõue: nali pidi olema terviklik, arusaadava mõtte moodustav tervik. Välja jäid naljade kordused, mis mingisugust variatsiooni kaasa ei toonud; korduvatest naljadest pääses valimisse ainult esimene ettejuhtuv. 
Kogu uuringus käsitletud naljamaterjal pärineb 2004. aastal loodud eesti kaasaegsete anekdootide andmebaasist. Andmebaas koondab nalju paljudest allikatest: nii rahvaluulearhiividest kui ka internetikogudest. Internetiallikad jagunevad staatilisteks naljakogudeks ja interaktiivseteks veebilehtedeks, kuhu kasutajad on saanud nalju lisada, samuti neid kommenteerida ja hinnata. Andmebaasis leiduv suulise päritoluga materjal pärineb vanemast perioodist, kuni aastani 1990. Käesoleva artikli seisukohalt pole suulise ja internetifolkloori eristamine kuigi oluline. Pealegi on veebikeskkonnal tänu interaktiivsusele loomulik sarnasus suulise kultuuriga. Siin artiklis kasutatud naljanäited pärinevad töö lõpus loetletud allikatest.

Lõplik analüüsimisele läinud naljade hulk oli 1869 (kui algsest 2000st oli lahutatud kõik poolikud ja korduvad naljad). Selle valimi analüüsimiseks kasutati kvalitatiivse tekstianalüüsi programmi QDA-miner, mis lisaks lihtsatele deskriptiivsetele funktsioonidele võimaldab ka näiteks loendada kodeeringute kokkulangevusjuhtumeid. Kogu materjal (1869 nalja) jaotati nelja suurde kategooriasse: 1) nalja asukoht, 2) teised tegelased naljas, 3) seksuaalne sisu, 4) naise positsioon naljas. Mitmete naljade puhul ei olnud kaht esimest kategooriat võimalik määratleda, ${ }^{3}$ aga seksuaalse sisu esinemine ja naise positsioon olid tuvastatavad kõigi naljade puhul. Nelja üldise liigitusega käisid kaasas mitmed alamkategooriad, mida analüüsiti eraldi ja teiste kategooriatega suhestades.

\section{Uuringu tulemused}

Ülevaade uurimistulemustest koosneb kahest osast. Esimene (3.1.) annab olulisemad numbrilised uurimustulemused 1869 naljast koosneva valimi kohta ja selgitab kasutatud kategooriate valikut. Teine osa ja selle alajaotused sisaldavad saadud andmete põhjalikumat analüüsi, ristates erinevaid kategooriaid ja jälgides nende koosesinemisi, tuues sealjuures näiteid kirevast naljamaterjalist. Kõik naljade kodeerimiseks kasutatud kategooriad ja alamkategooriad on leitavad artikli lõpus esitatud lisast.

\section{Üldine ülevaade}

Asukoht (edaspidi ka ruum) oli naljades tuvastatav 750 juhul. Ülejäänud juhtudel polnud asukohale viidatud või polnud see nalja situatsioonist kergesti järeldatav. 411 juhul toimus tegevus kodus, mis omakorda jagati neljaks alamkategooriaks: köök, magamistuba, elutuba, vannituba. Neist neljast oli kõige 
populaarsem elutuba 262 naljaga, järgnesid magamistuba, köök ja vannituba, viimane vaid mõne üksiku juhtumiga. Üks sellise jagunemise põhjus: kategooriat elutuba rakendati igal juhul, kui kodune õhkkond oli naljas implitseeritud, aga täpsele ruumile polnud viidatud. Teine suur alamkategooria asukoha all oli n-ö koduväline ruum, kus toimus isiklik suhtlus seal viibivate teiste isikutega. Selle alla läksid populaarseimatena arsti vastuvõtt / haigla / psühhiaatri juures (50 juhtumit), meelelahutuskohad kino, teater ja kasiino (39), politsei/kohtu (30), pood (28), töökoht (23), kool (19), restoran (14), kirik (6). Kolmas asukoha alamkategooria oli n-ö avalik ruum, kokku 130 esinemisjuhuga. See sisaldas kohti vabas õhus: linnaruum (70), ühistransport (33), looduskeskkond (27).

Suhtluspartnerid olid lihtsamini tuvastatavad kui asukoht, kokku 1657 naljas. Ülejäänud juhtudel polnud suhtluspartner tuvastatav, naine tegutses üksi või oli tegemist lühikese, tavaliselt küsimus-vastus vormis naljaga. Kahte laia alamkategooriasse jagunes suhtlus pereliikmetega (1139 nalja) ja inimestega väljaspoolt perekonda (518 nalja). Pereliikmed jagunesid esinemise populaarsuse järgi järgmiselt: abikaasa (802 nalja), lapsed/lapselapsed (264), ema/isa (61), sugulased abielu kaudu (8), koduloom (4). Inimesed väljaspool perekonda populaarsuse järjekorras: võõras (140), tööline (114), sõber (101), armuke (89), sõbranna (53), ülemus (21).

Seksuaalne sisu kategoriseeriti lihtsalt kas esinevana või mitte. Enamvähem selged vihjed ja keelemängud, samuti konkreetsed situatsioonid reetsid enamasti vastava sisu esinemise. Selgus, et seksuaalset materjali esines vaid $27 \%$ naljades.

Naise roll (positsioon) naljas pidi olema üks kõnekamaid kategooriaid sooliste stereotüüpide illustreerimiseks, kuid ühtlasi ka kõige raskemini ja subjektiivsemalt määratletav. Kõik naljad jaotati naise osalemise järgi kas 1) nalja objekti, "märklauana", 2) kõrvaltegelasena või 3) aktiivse peategelasena. Naise roll naljas määrati tavaliselt puändi järgi. Segasematel juhtudel jäid viimasteks instantsideks tervemõistuslik nalja lähilugemine ja intuitsioon. Tulemustest selgub, et 50\% juhtudest oli naine pelgalt kõrvaltegelane. Nendel juhtudel oli nali tegelikult millestki/kellestki teisest, naine polnud aktiivne kõneleja ega nalja objekt. Otseselt naise kulul oli $32 \%$ naljadest ja naine oli aktiivne nalja tegev pool $18 \%$ materjalist. 


\section{Tulemuste analüüs}

\section{Ruum ja suhtluspartnerid}

Hoolimata suurtest liberaalsetest arengutest, mis moodsas maailmas toimunud on, seostatakse naisi endiselt eelkõige koduse keskkonnaga. Nalja-materjal näib nende muutuste peegeldajana võrdlemisi vanamoeline $-22 \%$ naljadest leidis aset kodus. See protsent on suur, arvestades, et kasutati võimalikult neutraalseid märksõnu (mitte näiteks perenaine). Koduses keskkonnas on naise kaaslaseks anekdoodis tavaliselt pere - abikaasa, lapsed või vanemad. See tähendab, et esines vaid üksikuid kontakte mittesugulastega, tavaliselt sõbra või armukesega. Kodustest ruumidest on kõige neutraalsem ala elutuba, kus toimus suhtlus kõige suurema hulga erinevate partneritega; samas teistes tubades oli naine peamiselt ainult oma pereliikmetega. Kõige rohkem erandeid selles valdkonnas tõid armukese-naljad. Nende naljade skriptid ja puändid varieerusid väga laialt; ajastule omaselt esines ka selles, selgelt isikliku elu juurde kuuluvas naljateemas, nõukogude ajale omaseid puänte:

Mees leidis kodust naise koos armukesega ja tahtis hakata arveid õiendama. Naine aga pani kisama: "Sa ei tohi teda puutuda, ta on elus Leninit näinud!”

Oodatult said väljaspool kodu naise suhtluspartneriteks teised ühiskonnaliikmed, kes tema perekonda ei kuulu. Nende hulka kuulusid näiteks võõrad, töökaaslased ja ülemused. Tähistust "võõras” tuli populaarsemaina avalikus ruumis ette 34 korda. Nende naljade hulka kuulusid kohtumised varaste, vägistajate, kerjuste, teenindustöötajate, metsloomadega jpt. Tihti oli väljaspool kodu ettejuhtuv suhtluspartner ise nalja keskpunktis, muutes naise kõrvaltegelaseks, nagu järgnevas anekdoodis.

Tipptund. Peeter istub bussis isa süles. Bussi astub vana naine, kepp käes. Peeter hüppab püsti ja pöördub naise poole: "Palun istuge!"

See nali näitab ühtlasi kodeeringu tinglikkust, mis on tehtud rangelt naise vaatepunktist, ja seega nõudis nalja keskmes asuva isa ja poja kodeerimiseks kasutama tähistust "võõras".

Hoolimata keskkonnast (kas kodus või väljas) jäi abikaasa alati naise populaarseimaks kaaslaseks naljas. Teatud avalikes kohtades toimuvad naljad olid siiski erandeiks: arsti vastuvõtul, ühistranspordis ja poodides olid naise kaaslaseks vastavalt arst, võõras inimene ja müüja/teenindaja. 


\section{Seksuaalne sisu, ruum ja suhtluspartnerid}

Seksuaalsetel teemadel mängivate naljade hulk oli üllatavalt väike - 27\%, arvestades et sooga seotud naljad kipuvad seda teemat esile kutsuma ja neid nalju räägivad enamasti mehed omavahel. Üheks põhjuseks võivad olla neutraalsed otsingusõnad, mida materjali valimiseks kasutati. Seega välistati automaatselt palju blondiinide ja prostituutidega seotud nalju, mis harva seksuaalsest sisust vabad on. Nagu metodoloogia peatükis öeldud, selliseid nalju siiski esines, kuna neutraalsed naissugu tähistavad sõnad asusid tihti samas tekstis vähem neutraalsetega. Teine üllatav tendents oli, et seksiga seotud naljade tegevuskoht oli tihedamini ruumides väljaspool kodu. Koduste naljade keskmes olid elu proosalisema küljega seotud olukorrad, näiteks söögi tegemine ja laste naljad:

Noor ema vannitab oma beebit. Naabrite väike tütar, kes hoiab käes ilma jalata ja käeta nukku, jälgib seda toimingut ja küsib äkki: "Kaua ta sul on olnud?” - “3 kuud,” vastab ema. - "Siis on ta sul küll hästi vastu pidanud," hü̈̈atab tüdruk.

Noor abielunaine ohkab: "Keetsin täna esimest korda midagi lõunaks. Ja nü̈̈d on kass selle kõik ära söönud...” - "Kallim, ära kurvasta! Me ostame uue kassi."

Seksuaalse alatooniga juhtumid ja dialoogid toimusid nii väliskeskkonnas kui ka siseruumides:

Neiu hilineb kohtamisele. "Saa aru, kallis," selgitab neiu, "kogu tee jälitas mind mingi tüüp." - "No ja mis siis?” - "Sa lihtsalt ei kujuta ette, kui aeglaselt ta käis.”

Politseisse tuleb naine ja ütleb: "Just äsja vägistasid mind kaheksa meest." - “Ärge muretsege, küll me nad kinni nabime.” - "Aga kõiki pole vaja, ainult teine ja neljas.”

Seksiga seotud naljades oli naine harilikult aktiivne pool, kes (mehe üle) nalja tegi. Ilma seksuaalse sisuta naljades oli naine tavaliselt märklaud. Esimesel juhul on tähtsaima tegurina jälle mängus suhe abikaasaga/elukaaslasega; nalja aluseks on sageli paari jahenenud suhe, mis väljendub tavaliselt naise otsestes või kaudsetes etteheidetes oma mehele:

Ema, ema, mis asi see orgasm on? - Ma ei tea, mine küsi isa käest!

Seksiga seotud naljades on teised tegelased (peale abikaasa) tavaliselt võõras, armuke, aga ka lapsed ja vanemad. Üks tihti esinev naljateema on laste vara- 
jane huvi seksuaalsuse ja suhete vastu või varajased teadmised sellest. Neil juhtudel võib naine olukorrast olenevalt olla nii kõrvaltegelane kui ka nalja ohver.

"Isa, kui sa mulle raha annad, võin sulle rääkida, mida postiljon igal hommikul emale ütleb." - "Siin on 10 krooni, lase tulla." - "Tere hommikust, proua Metsis, siin on teie post."

Isa ja poeg jalutavad pargis ja näevad kahte koera seda suurte koerte asja tegemas. Poeg küsib isa käest, et mis nad seal teevad. Isa mõtleb ja ütleb, et tagumine koer lükkab esimest kodu poole. Poeg: "Siis on hea, et ema eile kraanikausist kinni hoidis, muidu oleks postiljon ta postkontorisse lükanud."

Naljades, kus seks kuidagi teemaks ei ole, on naise partneriks kõige tihemini naissoost sõber, ülemus, tööline/teenindaja ja loomulikult abikaasa. Järgnevad sõbrad, võõrad, sugulased, vanemad ja armuke. On raske kokkuvõtvalt öelda, millised on levinumad teemad mitteseksuaalsetes anekdootides, sest pilt on väga kirju. Tavalised rumaluse/nutikuse naljad, ämmanaljad, situatsioonil ja keelemängul põhinevad naljad, valimisse jäid ka mõned n-ö ebaõnnestunud või äärmiselt segaseks jääva mõttega naljad.

Materjali hulka jäi ka nalju, mille tegelasteks olid loomad, mis aga sellegipoolest peegeldasid sugudevahelisi suhteid:

Rebane läks Jänesele külla. Jänese imekena noorik kattis lauda. Juba tema nägemine võttis Rebasel silmad vilama, kuid iga pitsitäis pani Rebase vere veel rohkem vemmeldama. Kui pudel tühi, oli Rebane varmas raha pakkuma, et Jänes poest uue konjaki tooks. Rebase suureks rõõmuks oli viimane ettepanekuga kohe päri. Kuni peremees poes käis, võrgutas Rebane Jänese nooriku ära. Kui Jänes poest tagasi jõuab, mõnuleb Rebane tugitoolis, sigar suus, jalg üle põlve ja kiidab: "Sa, Jänes, oled täitsamees. Ise oled selline lontkõrvaline kõõrdsilm, aga millise suurepärase naise sa endale oled saanud!”- "Mis naise?” ei taipa Jänes. "Naine sõitis hommikul suvilasse. See siin on minu täditütar. Ta tuli linna AIDS-i ravima!!!”

\section{Naise roll/positsioon naljades}

Esimene probleem selle kategooria juures on fakt, et väga suures hulgas $-50 \%$ naljadest - on naine üksnes kõrvaltegelane. Ainuüksi see number näib kinnitavat teooriaid, et naljade rääkimine on selgelt meeste tegevusala (Kuipers 2006). 
Naljamaterjali üle lugedes on tajutav, et enamik peategelastest on mehed ja sellele vastavalt toimivad ka naljad. Üllatuslikult on naine kõrvaltegelane ka naljades, mis eeldaksid näiliselt tema suuremat osalust, näiteks armukeseteemade puhul. Selgub, et nendel juhtudel on keskmes pigem situatsioon ise, eriti aga armukese põgenemisviisid ja abikaasa reaktsioonid petmisele peale sattumisel.

“Tere päevast, Robert! Kas ma saaksin sinu abikaasaga rääkida?”- "Kahju küll, aga praegu ei saa kuidagi. Ta on nimelt voodis...” - "Taevake! Kas ta on haige?" - "Ei, tal on külaline."

Näib, et n-ö abielurikkumisnaljade puhul ei naeruvääristata naist ega näidata teda eriti halvas valguses (abielurikkumine on juba iseenesest ebamoraalne tegu). Pigem on tema roll neutraalne.

Naljades koos oma vanemate ja teiste sugulastega, samuti abikaasaga on naine enamasti nalja aktiivne pool. See tähendab, et ta kritiseerib ja teeb teiste kulul nalja, kaitseb oma vaatepunkte. Sugulastega suheldes on mõju ka vanuselistel hierarhiatel, nii teeb mõnikord ema nalja oma vähekogenud tütre üle. See ei ole aga reegel ning sellised naljad töötavad ka vastupidi.

Juku ütleb emale: "Memm, sul on juba mitu halli juust peas." - "See on laste sõnakuulmatus, mis vanemate pead halliks teeb." Hetke pärast lausub Juku: "Nü̈̈d on selge, miks vanaema pea on täitsa hall."

Koos ämma või äiaga ühes naljas tegutsedes on naine harilikult nalja märklaud. Tema kulul tehakse nalja ka ülemusega lävides. Suheldes oma abikaasaga on naine nalja objekt ootamatult harva: vaid 2,5\% juhtudest, kui abikaasa on mainitud. Proovides teha üldistusi naise rolli ja suhtluspartnerite kohta, võib öelda, et naisel on anekdootides olulisem roll (ükskõik, kas nalja subjekti või objektina) oma sugulastega suheldes. Võõrastega lävides on ta pigem kõrvaltegelane. Seega näib edasi elavat ka klassikaline müüt naistest kui kodu eest vastutajatest ja nende vähesest osalusest sotsiaalses elus väljaspool kodu.

Probleemne on ka naise kuvand nendes naljades, kus tema roll on aktiivne. Neid nalju lugedes tekib paratamatult küsimus, kas seal on esindatud naise vaatepunkt, või pigem nalja rääkiva mehe representatsioon naisest. Naise aktiivset rolli anekdootides jälgides saab selgeks, et tal pole just palju võimalusi enda kehtestamiseks. Kui vaadata eraldi nalju, kus naised suhtlevad omavahel, ning nalju, kus naine suhtleb mehega, märkame, kui kitsastes piirides naishääl tegelikult liigub. Selgub, et naljades, kus mehi kohal pole, keerleb jutt enamasti ikka meeste ümber, teemaks nende rumalus ja truudusetus. Juhtudel, kui jutt ei käi ühestki mehest, võib nali kõlada ka teise naise kulul: 
Kaks naabrinaist riputavad pesu kuivama. Üks märkab, kuidas teine tema pesu jõllitab ning küsib: "Miks sa mu riideid niimoodi jõllitad, kas sa teed enda omadega kuidagi teistmoodi?" - "Jah," vastab teine, "ma pesen enda omi enne kuivama riputamist."

Kui naine teeb nalja mehe üle, on märklauaks harva mõni võõras mees, pigem ikka naise abikaasa. Samuti võib mees sattuda märklauaks siis, kui naine suhtleb tegelikult oma lapsega.

"Ema, ma võin su kirja postkontorisse viia." - "Ei, vaata, missugune ilm väljas on, hea peremees ei laseks oma koeragi sellisega välja. Las su isa parem viib."

Seega on meil ka naise aktiivse osalemise korral naljas tegu ikkagi naise stereotüüpse häälega mehe loodud maailmas. Kui naise aktiivne roll eeldaks teatud enesekehtestust, oma õiguse maksma panemist, siis anekdoodimaailmas piirduvad naiste soovid enamasti seksuaalse rahulduse nõudmisega, nagu järgnevas näites:

"Lähme magama, või mis?” küsib mees. - "Enne või mis ja siis magama," vastab naine.

Kalduvus naisi naljades teatud viisil presenteerida pärineb arvatavasti meeste kollektiivse identiteedi konstrueerimise lätetelt. Selle protsessi käigus naistele omistatud ühised nimetajad kalduvad paratamatult olema stereotüüpsed; äärmuste ja vastandamisega tegelevas žanris nagu anekdoot tihti ka ühekülgselt solvavad. Tahtmata anda hinnanguid sellistele protsessidele, tuleb lisada, et teatud tüüpi stereotüüpsete naljade menu on põhjendatud ka mõnede sotsiaalsete institutsioonide ja protsesside sisemise vastuolulisusega. Silmatorkavaim neist on siinses töös kindlasti abielu, esmalt juba suure esinemissageduse tõttu (vt abikaasa esinemise tihedust naise suhtluspartnerina). Abielu ambivalentne iseloom on see, mis psühhoterapeudist huumoriuurija Herbert Streani (1977: 87) sõnul nalju tekitab. Inimesed teavad abielu võimalikke probleeme, kuid abielusid sõlmitakse jätkuvalt ja sellel traditsioonil ei näi lõppu tulevat. Tüdimus, alaväärsus, agressioon, võimetus oma partnerit austada on abielu kui institutsiooni negatiivsed nähted, mis naljadele lõputult ainest annavad. Ka sellest küljest vaadatuna reedavad uuritud naljad eelkõige meeste vaatepunkte. See väljendub näiteks naljades, kus jõuline naine oma mehe üle domineerib, ta kuidagi paika paneb. Hoolimata sellest, et naine on naljas aktiivne pool, pärineb nali selgelt meestele omasest hirmust jääda tallaaluseks ning naerdakse sookaaslase üle, kellega see juhtunud on. Enamik nalju aktiivse naistegelasega viitab selgelt tagasi maailmale, kus meestel on domineeriv roll ning selles maailmas käibiv naisekuvand on enamasti jämedalt stereotüüpne. Esile 
tulevad põhiliselt järgmised omadused: näägutav, domineeriv, manipuleeriv, kaval, nümfomaanlik või seksi vastu huvi kaotanud.

Janet Bing (2007: 359-360) on loetlenud viise, kuidas naised saaksid oma vaatepunkte huumori kaudu kuuldavamaks teha. Ühe võimalusena näeb ta juba ringlevate naljade ümberpööramist (role-reversal), asendades meestegelased naistegelastega. See meetod ei pruugi küll paljude naljade puhul toimida, kuid mõnel juhul siiski. Käesolevas naljamaterjalis esines rollivahetust ainult paaril korral. Feministliku suunitlusega huumor on loomult kriitiline ja osutab tavaliselt mingile ebaõiglusele või absurdsusele. Kui nõukogude ajal seostus absurdsus igapäevaeluga ja oli üldlevinud komme seda anekdootides kritiseerida, siis tänapäeval on olukord üldiselt keerulisem. Raskem on kindlaks teha ühiskonna kitsaskohti, selle suhtes puudub nii selge konsensus. Naised pole ühiskonnas vähemusrühm, aga nende kriitilisel häälel on tänapäeval kindlasti palju arengupotentsiaali. Näib, et eesti internetinaljade andmebaasidesse ja portaalidesse pole see võimalus veel jõudnud, naisi puudutavas materjalis annab tooni üldiselt vanamoelisus ja klišeelisus.

\section{Kokkuvõte}

Sugudevahelisi suhteid puudutav huumor, nagu ka etniline huumor, on levinud kogu maailmas. Põhiliselt räägivad neid nalju mehed, kuigi kuulamiseks ja naermiseks on need suunatud kõigile. Käesolev uurimustöö tegeles naiste kujutamisega eesti anekdootides, et selgitada, milline on käibelolev kuvand naistest ja kui stereotüüpne see on. Selleks vaadeldi 1869 naljast koosnevat valimit. Kodeeringud jaotasid naljad nelja laia kategooriasse, mis andsid informatsiooni naisi anekdootides ümbritseva ruumi, suhtluspartnerite, seksuaalse sisu ja naise rolli aktiivsuse kohta.

Ümbritseva ruumi kohta saadud andmed olid võrdlemisi tagasihoidlikud, sellele oli viidatud vähem kui pooltes naljades. $22 \%$ selge asukohaga naljades tegutses naine kodus, kus tema kaaslasteks olid põhiliselt pereliikmed. Väljaspool kodu suhtles naine enamasti võõraste või pereväliste tuttavatega.

Suhtluspartneritest domineeris populaarseimana naise abikaasa. Järgnesid lapsed, võõrad, töölised/teenindajad, sõbrad ja armuke. Seksuaalse materjali vähene esinemine $(27 \%)$ oli üllatav, üheks põhjuseks oli ilmselt võimalikult neutraalselt valitud otsingusõnad. Seksuaalse sisuga naljade tegevus toimus tavaliselt väljaspool kodu, kodus toimuvates naljades domineerisid proosalisemad stsenaariumid. Põhiliseks erandiks selles vallas olid väga levinud armukesenaljad. 
Tähtis kriitiline aspekt naljade analüüsimise juures oli neljas kodeeringutekategooria, mis üritas tuvastada naise rolli (positsiooni) naljas. See kõige raskemini tuvastatav (seega ka vaieldav) aspekt näitas, et pooltes kõigist naljadest jäi naisele marginaalne kõrvaltegelase roll. See kinnitab üsna veenvalt sotsioloogilist hüpoteesi, et naljade rääkimine on põhiliselt meeste tegevus. Naise kuvand oli sarnane hoolimata tema rollist ja selle osatähtsusest naljas. See levinud kujutamisviis on selgelt vanamoeline ja stereotüüpne, peegeldades eelkõige meeste dominantset identiteeti ja patriarhaati ohustavat naisekuju. Võib julgelt väita, et eesti internetiandmebaasides sisalduvates naljades on feministlik potentsiaal, nii nagu seda näeb näiteks Janet Bing, suuresti kasutamata. Rollivahetust esineb väga harva, samuti sarkastilist ja iroonilist lähenemist, mis kritiseeriks meedias ja avalikkuses liigselt kinnistunud ja kahjulikke stereotüüpe.

Esmapilgul võib üldistades öelda, et uuritud materjal on ühiskonna arengute suhtes staatiline. See kinnitab muuseas väidet, et naljade põhjal ei saa teha suuri üldistusi sotsiaalse tegelikkuse kohta (Davies 2011: 2). 21. sajandi eesti ühiskond pole kindlasti sama, mis oli nõukogudeaegne. Naistegelase representatsioon on aga suhteliselt ühetaoline kogu materjali ulatuses, alludes klassikalistele vastandustele rumal-tark, domineeriv-passiivne, seksuaalselt üliaktiivne, seksuaalsete huvideta. Naist kujutatakse suuresti meeste maailma ja selle juurde kuuluvate väärtuste vaatepunktist. Kuidas seda vähest muutumist seletada? Usun, et esiteks on siin vaja pöörata tähelepanu anekdoodižanrile endale. Näib kinnitust leidvat, et žanri vormitunnuseid ei saa vaadata täiesti eraldi selles ilmnevast sisust, need poolused sõltuvad üksteisest. Nii tingib anekdoodi jäik vorm osalt ise selles esinevate mõtete sarnasuse. Ühiskonnas tekkivad uued diskursid sisenevad sellesse vormi vaevaliselt, rikkudes uue sisuna ühtlasi vormi spontaanse toimimise. Teine, metodoloogiast lähtuv mööndus nii ühese pildi kohta tuleneb selle suure hulga naljade tõlgendamisest, kus naistegelane oli näiliselt tähtsusetus rollis. On väga tõenäoline, et mõni teine uurija leiaks nendes naljades rohkem naise suhtes positiivseid hoiakuid. Neljanda kategooria "naise roll” määratlemine ongi tegelikult võimatu ilma teatud hinnanguliste (või ka ideoloogiliste) eelhoiakuteta. Kolmas, tulemuste psühholoogiline selgitus seostab soolise ja seksuaalse identiteedi primaarse koha inimese elus ning huumori sotsiaalse külje. Kui näha anekdooti suulise ja spontaanse suhtluse osana, mida kasutatakse identiteedi ja solidaarsuse loomiseks rühmas, on üsna loomulik, et suhtluses otsitakse ühisosi rühma liikmete vahel. Selle ühisosa leidmise nimel samastatakse oma vaateid juba kehtivate normidega ja pigem hoidutakse rühma sulandumise eesmärgil oma individuaalse ja nüansseeritud vaatepunkti rõhutamisest. See on eriti mõistetav nii õrnas ja isiksust konstitueerivas valdkonnas nagu sooline identiteet, mille 
puhul on inimese jaoks palju kaalul. Niimoodi taastoodetakse ja kinnistatakse spontaanses naljatamises vanu "kindlalt töötavaid" šabloone, et mitte väljuda suhtluse mugavustsoonist ja tagada samastumisel põhinevat meelelahutust rühma võimalikult paljudele liikmetele.

Need mõtted lubavad lõpetada siinse käsitluse positiivsema tooniga. Ehk peaksime hülgama lootuse leida anekdoodižanrist liberaalsemat ja vananenud tõdesid õonestavat häält. See ei tähenda, et peaksime need tõed uuesti omaks võtma, selle asemel tuleb pöörata pilgud uuemate žanride poole. Ehk võime sealt leida nüansseeritumaid vaateid, mis kannavad uuema ajastu vaimu ka sooteemalise huumori vallas.

\section{Kommentaarid}

1 International Summer School for Humour Studies toimus 2011. aastal Tartus. Lähem info veebilehelt http://humoursummerschool.org/11/index.html.

2 Jewish american princess on halvustav stereotüüp USAs elavatest juudi soost naistest. Selle kuvandi järgi iseloomustab neid materialistlik maailmavaade, laiskus ja huvi puudumine seksi vastu.

${ }^{3}$ Põhjuseks oli tavaliselt naljade lakoonilisus, enamik neist naljadest olid väga lühikesed, tihti küsimus-vastus ülesehitusega.

\section{Allikad}

Delfi. Delfi naljaleht (http://vimka.delfi.ee/?filter=anecdote - 16. november 2012).

Eesti Päevaleht. Eino Baskini anekdoodid eesti kaasaegsete anekdootide andmebaasis (http://www.folklore.ee/ liisi/o2/ - 16. november 2012).

Ivar Kallion 2011. Nõuka-aja anekdoodid. Tallinn: Tammerraamat.

Jüri Viikberg 1997. Naeruga eilsest. Tallinn: Eesti Keele Sihtasutus.

Kuldar Metsa naljakogu Eesti kaasaegsete anekdootide andmebaasis (http://www.folklore.ee/ liisi/o2/ - 16. november 2012).

Meie naljaraamat. Eesti kaasaegsete anekdootide andmebaas (http://www.folklore. ee/ liisi/o2/ - 16. november 2012).

Sõnumileht Online. Eesti kaasaegsete anekdootide andmebaas (http://www.folklore. ee/ liisi/o2 - 16. november 2012). 


\section{Kirjandus}

Billig, Michael 2001. Humour and hatred: The racist jokes of the Ku Klux Klan. Discourse and Society 12, lk 267-289 (doi:10.1177/0957926501012003001).

Bing, Janet 2007. Liberated jokes: Sexual humor in all-female groups. Humor. International journal of humor research 20 (4), lk 337-366 (doi:10.1515/HUMOR.2007.017).

Crawford, Mary 2003. Gender and humor in social context. Journal of Pragmatics 35 (9), lk 1413-1430 (doi:10.1016/S0378-2166(02)00183-2).

Davies, Christie 1998. Jokes and their relations to society. Humor Research 4. Berlin \& New York: Walter de Gruyter (http://dx.doi.org/10.1515/9783110806144).

Davies, Christie 2011. Jokes and targets. Bloomington: Indiana University Press.

Kuipers, Giselinde 2006. Good humor, bad taste: A sociology of the joke. Humor Research 7. Berlin \& New York: Mouton de Gruyter.

Kuipers, Giselinde 2008. The sociology of humor. Raskin, Victor (toim). The Primer of Humor Research. Humor Research 8. Berlin: Mouton de Gruyter (doi:10.1515/978311 0198492.361).

Laineste, Liisi 2003. Researching humor on the internet. Folklore: Electronic Journal of Folklore 25, lk 93-97 (http://www.folklore.ee/folklore/vol25/humor.pdf - 16. november 2012).

Oring, Elliott 2003. Engaging humour. Chicago: University of Illinois Press.

Rappoport, Leon 2005. Punchlines. The case for racial, ethnic, and gender humor. London: Praeger/Greenwood Press.

Shifman, Limor \& Lemish, Dafna 2010. Between feminism and fun(ny)mism: Analyzing gender in popular Internet humor. Information, Communication and Society 13 (6), lk 870-891.

Shifman, Limor \& Lemish, Dafna 2011. "Mars and Venus" in virtual space: Post-feminist humor and the Internet. Critical Studies in Media Communication 28 (3), august, lk 253-273 (doi:10.1080/15295036.2010.522589).

Stanoev, Stanoy 2010. Dumb blondes and democracy. Folklore: Electronic Journal of Folklore 46, lk 43-60 (http://www.folklore.ee/folklore/vol46/stanoev.pdf - 16. november 2012).

Strean, Herbert S. 1977. Jokes. Their purpose and meaning. Northvale, New Jersey: Jason Aronson Inc.

\section{Lisa: Kasutatud kategooriad}

Paksus kirjas on trükitud kõik üldised kategooriad, tavalises kirjas kõik alamjuhud, mis liigitamisel esinesid. 


\section{Nalja toimumise asukoht}

$1.1 \mathrm{Kodu}$

1.1.1. Köök

1.1.2. Elutuba

1.1.3. Magamistuba

1.1.4. Vannituba

1.2 Väljaspool kodu, isiklik ruum

1.2.1. Arsti, psühhiaatri vastuvõtt / haigla

1.2.2. Pood

1.2.3. Restoran

1.2.4. Kohtus/politsei

1.2.5. Meelelahutus (teater, kino, kasiino)

1.2.6. Kirik

1.2.7. Kool

1.2.8. Tööl

1.3. Väljaspool kodu, avalik ruum

1.3.1. Ühistransport

1.3.2. Linnaruum (tänav, park)

1.3.3. Loodusruum (rand, mets)

\section{Suhtluspartnerid naljas}

2.1. Pereliikmed

2.1.1. Lapsed/lapselapsed

2.1.2. Abikaasa

2.1.3. Ema/isa

2.1.4. Sugulased abielu kaudu

2.1.5. Koduloom

2.2. Inimesed väljaspoolt perekonda

2.2.1. Armuke

2.2.2. Tööline

2.2.3. Võõras

2.2.4. Sõber

2.2.5. Sõbranna

2.2.6. Ülemus

\section{Seksuaalne sisu}

3.1. Esineb

3.2. Ei esine 


\title{
4. Naise positsioon naljas
}

\author{
4.1. Nalja märklaud \\ 4.2. Subjekt, nalja tegija \\ 4.3. Nalja kõrvaltegelane
}

\section{Summary}

\section{Representation of woman in contemporary Estonian jokes: critical survey}

\author{
Indrek Ojam
}

Keywords: feminism, gender, humor-research, internet-humor

This article discusses the representation of woman in Estonian punch-lined jokes. After brief introduction to the problems and approaches of this field the author presents the results of the extensive research, which consisted of the survey of 1869 jokes. Jokes representing female characters had to contain one of the four most neutral keywords: woman, mother, wife and maiden (young woman in Estonian). These jokes were collected from the Internet and stem from the years 1960-2010 and are categorised using the program QDA-miner, which enables both quantitative and qualitative methods. However, the main emphasis in the approach is on the critical interpretation of the results.

The jokes were divided into 4 major subcategories: 1) location of the joke; 2 ) the interaction partners of woman; 3 ) sexual content; 4) the role of the woman (active, submissive, neutral). The most frequent location for the joke was homely environment. Woman interacted in the jokes mostly with her husband, children and other family members. Surprisingly, only $27 \%$ of the material contained any kind of sex-related circumstances. The fourth and most ambiguous (open to interpretation) category was the role of the woman. It was also the focal point of my critical approach. The results show generally, that the picture of woman in Estonian jokes is rather passive and one-sided. In literally half of the jokes, woman had merely episodical role. Woman was clearly the target of the joke in $32 \%$ of the jokes and active protagonist in the rest $18 \%$. Although it seems, that the female character had often something meaningful to say in jokes, closer look reveals that it was not the case. Even in the jokes where the woman was active, her role was still very stereotypical and reflected rather the point of view of men telling the jokes or the construction of male identity in general.

These tendencies show, that the representation of woman in estonian joke material is quite static throughout the period of 1960 s until the first decade of the 21st century. I maintain, that this phenomenon cannot be explained with the simple persistence of sexism and misogyny in society. One other way of explaining it, is that the inherent stability of the genre of punch-lined joke does not let new discourses appear in it. Researchers should look for other new humorous genres for more critical and complex representation of gender and femininity. 